\title{
Promotion of Nutrient Uptake, Nutrient Use Efficiency and Apparent Nutrient Recovery of Wheat (Triticum aestivum L.) by Application of Phosphate and Potash Solubilizing Bacteria
}

\author{
N.V. Savaliya ${ }^{1 *}$, Vipen Bhadu ${ }^{1}$, R.A. Barsiya ${ }^{1}$ and B.M. Vadaliya ${ }^{2}$
}

${ }^{1}$ Department of Agronomy, ${ }^{2}$ Department of Soil Science and Agricultural Chemistry, College of Agriculture, Junagadh Agricultural University, Junagadh, (Gujarat) India

*Corresponding author

\section{A B S T R A C T}

\section{Keywords}

Nutrient Uptake,

Nutrient Use

Efficiency,

Apparent Nutrient

Recovery and

Phosphate and

Potash Solubilizing

Bacteria

\section{Article Info}

Accepted:

17 June 2018

Available Online:

10 July 2018
A field experiment was conducted on calcareous clayey soil at Junagadh (Gujarat) during rabiseason of 2014-15 to study the effect of phosphate and potash solubilizing bacterial inoculations on of nutrient uptake, nutrient use Efficiency and apparent nutrient recovery of Wheat (Triticum aestivum L.). The experimental results revealed that application of $45 \mathrm{~kg} \mathrm{P} \mathrm{O}_{5} / \mathrm{ha}+$ phosphate solubilizing bacteria (PSB) seed inoculation + PSB soil application, being statistically at par with application of $45 \mathrm{~kg}$ $\mathrm{P}_{2} \mathrm{O}_{5}+\mathrm{PSB}$ seed inoculation, significantly promoted phosphorus uptake by grain $(17.98 \mathrm{~kg} / \mathrm{ha})$ and straw $(5.72 \mathrm{~kg} / \mathrm{ha})$ as well as NUE of applied P $(14.97 \mathrm{~kg}$ grain $/ \mathrm{kg} \mathrm{P}$ applied) and apparent nutrient recovery of $\mathrm{P}$ by $15.11 \%$. While, Application of $45 \mathrm{~kg}$ $\mathrm{K}_{2} \mathrm{O} / \mathrm{ha}+\mathrm{KSB}$ seed inoculation $+\mathrm{KSB}$ soil application $\left(\mathrm{K}_{3}\right)$ recorded significantly highest potassium uptake by grain $(18.27 \mathrm{~kg} / \mathrm{ha})$ and straw $(69.92 \mathrm{~kg} / \mathrm{ha})$. The treatment $\mathrm{K}_{3}\left(45 \mathrm{~kg} \mathrm{~K} \mathrm{~K}_{2} \mathrm{O} / \mathrm{ha}+\mathrm{KSB}\right.$ seed inoculation $+\mathrm{KSB}$ soil application) registered the highest potash use efficiency $(15.73 \mathrm{~kg}$ grain $/ \mathrm{kg} \mathrm{K}$ applied) and apparent potash recovery $(67.37 \%)$.

\section{Introduction}

Wheat (Triticum aestivum L.) is one of the most important staple food crop cultivated in almost all the countries in the world. It's belonging to "Gramineae" family. Wheat is the second most important grain crop of India after rice and thus crucial for the food security of the country. It is the world's most cultivated food crop. It is eaten in various forms by more than one thousand million human beings in the world. In India it is second important staple food crop, rice being the first.

Wheat provides about $20 \%$ of total food calories for the human race. Wheat grain contains about 12.2 per cent protein and the gluten in the grain provides the structural framework for the spongy, cellular texture of bread and bakery products. Wheat has a relatively high content of niacin and thiamine. Wheat straw is a good source of cattle feed, 
used in paper industries and for making temporary huts and roofs. Wheat straw is also a good source of bedding material for livestock. Wheat can be grown on a variety of soils ranging from sandy to heavy clay, however, fertile and well-drained loam to clay loam soil is most suitable for higher production.

Wheat production in India is 93.50 million tonnes during 2015-16 which is higher by 6.97 million tonnes than the production of 86.53 million tonnes achieved during 2014-15. The major wheat growing states in India are Gujarat, Uttar Pradesh, Punjab, Haryana, Madhay Pradesh and Rajasthan. The average wheat productivity of India is $3093 \mathrm{~kg} / \mathrm{ha}$ (Anonymous, 2017).

The fertilizer is essential as well as expensive input in agricultural production. Fertilizer plays a leading role in increasing crop production by almost $41 \%$. The fertilizer recommendations need to be matched to genetic materials and agro-climatic situations to exploit potential yield of wheat.

Natural phosphate rocks have been recognized as a valuable alternative for $P$ fertilizers. In India, it is estimated that there are almost 260 million tonnes of phosphate rock deposits and this material should provide a cheap source of phosphate fertilizer for crop production. Unfortunately, rock phosphate (RP) is not readily available to the plants in soils with a $\mathrm{pH}>5.5-6.0$ (Illmer and Schinner, 1995). Several P-solubilizing microorganisms have the ability to convert insoluble low grade rock phosphates into soluble forms available for plant growth. Potassium $(\mathrm{K})$ is an essential macronutrient and most abundantly absorbed cation that play an important role in the growth, metabolism and development of plants. Without adequate potassium, the plants will have poorly developed roots, grow slowly, produce small seeds and have lower yields. Although, potassium constitutes about 2.5 per cent of the lithosphere but actual soil concentrations of this nutrient vary widely ranging from 0.04 to 3.0 per cent.

Certain bacteria are capable of decomposing minerals and releasing a portion of the phosphate and potassium contained therein (Basak and Biswas, 2009). In addition, phosphate and potash solubilizing bacteria are also known to produce amino acids, vitamins and growth promoting substances like indole3-acetic acid (IAA) and gibberellic acid (GA3) which help in better growth of the plants (Ponmurugan and Gopi, 2006). Solubilization of phosphate and potassium from the potassium aluminium silicate and rock phosphate by the selected bacterial strains resulted to the action of different organic acids like citric, oxalic, malic, succinic and tartaric acid.

Thus, application of $\mathrm{P}$ and $\mathrm{K}$ solubilizing bacteria as biofertilizer for agriculture improvement can reduce the use of agrochemicals, improve nutrient use efficiency and support eco-friendly crop production. Considering the facts and to bridge the research gap highlighted above, the present experiment was undertaken during the rabi season of 2014-15.

\section{Materials and Methods}

The experimental soil was medium black calcareous clayey and slightly alkaline in reaction with $\mathrm{pH} 7.9$ and $\mathrm{EC} 0.33 \mathrm{dS} / \mathrm{m}$, medium in available nitrogen $(254-269 \mathrm{~kg} / \mathrm{ha})$, available phosphorus (28.4-30.7 kg/ha) and available potash (183-185 kg/ha). The experiment comprise of 16 treatment combinations consisting of four levels of PSB $\left(\mathrm{P}_{0}\right.$ : Control, $\mathrm{P}_{1}: 60 \mathrm{~kg} \mathrm{P}_{2} \mathrm{O}_{5} / \mathrm{ha}, \mathrm{P}_{2}: 45 \mathrm{~kg}$ $\mathrm{P}_{2} \mathrm{O}_{5} / \mathrm{ha}+\mathrm{PSB}$ seed inoculation, $\mathrm{P}_{3}: 45 \mathrm{~kg}$ $\mathrm{P}_{2} \mathrm{O}_{5} / \mathrm{ha}+\mathrm{PSB}$ seed inoculation + PSB soil application) and four levels of $\mathrm{KSB}\left(\mathrm{K}_{0}\right.$ : 
Control, $\mathrm{K}_{1}: 60 \mathrm{~kg} \mathrm{~K}$ O/ha, $\mathrm{K}_{2}: 45 \mathrm{~kg} \mathrm{~K}$ O/ha $+\mathrm{KSB}$ seed inoculation, $\mathrm{K}_{3}: 45 \mathrm{~kg} \mathrm{~K} 2 \mathrm{O} / \mathrm{ha}+$ KSB seed inoculation + KSB soil application). These treatments were replicated thrice in a randomized block design. Dose of nitrogen i.e. $120 \mathrm{~kg} \mathrm{~N} / \mathrm{ha}$ in two equal splits at sowing and 25 DAS was applied uniformly to all the plots. Entire dose of phosphorus and potash as per treatments was applied in form of diammonium phosphate and muriate of potash, respectively at sowing. Liquid formulation of PSB (Bacillus coagulans) and KSB (Frateuria aurantia) were used for seed treatment as well as for soil application. For seed treatment, seeds were spreaded and PSB/KSB culture (108 viable cells/g) @ 30 $\mathrm{mL} / \mathrm{kg}$ of seed was sprinkled on the seeds and then dried in shade. For soil application, PSB/KSB culture (108 viable cells/g) @ 3000 $\mathrm{mL} / \mathrm{ha}$ was applied in furrows just after sowing before irrigation. The crop was raised as per the recommended package of practices.

\section{Nutrient use efficiency}

Nutrient use efficiency was calculated with the help of the following formula.

(Panda, 2012)

Nutrient use efficiency ( $\mathrm{kg}$ grain $\mathrm{kg}$ fertilizer) $=\frac{\mathrm{Yf}-\mathrm{Yc}_{\mathrm{c}}}{\mathrm{Fa}_{\mathrm{a}}}$

Where; Yf $=$ Yield (grain or any other economic produce) under the fertilized plotin $(\mathrm{kg} / \mathrm{ha}$ ), Yc $=$ Yield (grain or any other economic produce) under the control (no fertilizer) plot $(\mathrm{kg} / \mathrm{ha}), \mathrm{Fa}=$ Fertilizer applied ( $\mathrm{kg} / \mathrm{ha})$

\section{Apparent Nutrient Recovery (NR)}

Apparent nutrient recovery was calculated with the help of the following formula (Panda, 2012)

Apparent nutrient recovery $(\%)=\frac{\mathrm{Uf}-\mathrm{Uc}}{\mathrm{Na}} \times 100$
Where; Uf = nutrient uptake by fertilized plot $(\mathrm{kg} / \mathrm{ha}), \mathrm{Uc}=$ nutrient uptake by control plot $(\mathrm{kg} / \mathrm{ha}), \mathrm{Na}=$ nutrient applied $(\mathrm{kg} / \mathrm{ha})$

\section{Results and Discussion}

\section{Effect of PSB}

Different levels of PSB exhibited significant impact on phosphorus uptake by grain and straw. Significantly the highest phosphorus uptake by grain and straw $(17.98,5.72 \mathrm{~kg} / \mathrm{ha}$, respectively) was recorded with application of $45 \mathrm{~kg} \mathrm{P}_{2} \mathrm{O} 5 / \mathrm{ha}+\mathrm{PSB}$ seed inoculation $+\mathrm{PSB}$ soil application $\left(\mathrm{P}_{3}\right)$, nevertheless it remained statistically at par with application of $45 \mathrm{~kg}$ $\mathrm{P}_{2} \mathrm{O}_{5} /$ ha + PSB seed inoculation $\left(\mathrm{P}_{2}\right)$. Total uptake of phosphorus also follows the same trend as in grain and straw. Application of 45 $\mathrm{kg} \mathrm{P}_{2} \mathrm{O} 5 / \mathrm{ha}+\mathrm{PSB}$ seed inoculation + PSB soil application $\left(\mathrm{P}_{3}\right)$ registered $23.71 \mathrm{~kg} \mathrm{P}$ ha $^{-1}$ uptake over control (16.90 kg/ha). Potassium uptake by grain and straw was also influenced by PSB. Among different levels of PSB, application of $45 \mathrm{~kg} \mathrm{P}_{2} \mathrm{O}_{5} / \mathrm{ha}+\mathrm{PSB}$ seed inoculation + PSB soil application $\left(\mathrm{P}_{3}\right)$ recorded significantly the highest potassium content by grain $(17.14 \mathrm{~kg} / \mathrm{ha})$ and straw $(66.76 \mathrm{~kg} / \mathrm{ha})$ as well as total potassium uptake $(83.89 \mathrm{~kg} / \mathrm{ha})$, which was statistically at par with application of $45 \mathrm{~kg} \mathrm{P}_{2} \mathrm{O}_{5} / \mathrm{ha}+\mathrm{PSB}$ seed inoculation $\left(\mathrm{P}_{2}\right)$ and $60 \mathrm{~kg} \quad \mathrm{P}_{2} \mathrm{O}_{5} / \mathrm{ha}\left(\mathrm{P}_{1}\right)$. Application of $45 \mathrm{~kg} \mathrm{P}_{2} \mathrm{O}_{5} / \mathrm{ha}+\mathrm{PSB}$ seed inoculation + PSB soil application $\left(\mathrm{P}_{3}\right)$ recorded the highest phosphorus use efficiency (14.97 kg grain/kg P applied) and apparent nutrient recovery $(15.11 \%)$, followed by application of $45 \mathrm{~kg} \mathrm{P}_{2} \mathrm{O}_{5} / \mathrm{ha}+\mathrm{PSB}$ seed inoculation $\left(\mathrm{P}_{2}\right)$ having phosphorus use efficiency of $11.44 \mathrm{~kg}$ grain $/ \mathrm{kg} \mathrm{P}$ applied and apparent phosphorus recovery of $11.67 \%$.

Among different levels of PSB, application of

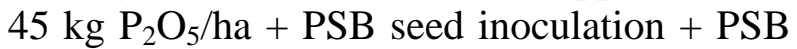
soil application $\left(\mathrm{P}_{3}\right)$ recorded the highest potash use efficiency $(9.13 \mathrm{~kg}$ grain $/ \mathrm{kg} \mathrm{K}$ 
applied) and, followed by application of 45 $\mathrm{kg} \mathrm{P}_{2} \mathrm{O}_{5} / \mathrm{ha}+\mathrm{PSB}$ seed inoculation $\left(\mathrm{P}_{2}\right)$ having phosphorus use efficiency of $7.48 \mathrm{~kg}$ grain/kg K applied and apparent potash recovery $(41.22 \%)$, followed by application of $45 \mathrm{~kg} \mathrm{P}_{2} \mathrm{O}_{5} / \mathrm{ha}+\mathrm{PSB}$ seed inoculation + PSB soil application $\left(\mathrm{P}_{3}\right)$ having apparent phosphorus recovery of $37.72 \%$.

PSB solubilized the fixed soil phosphorus and readily hydrolysed the organophosphate and degraded them in the soil and increase the availability of fixed $\mathrm{P}$ and applied $\mathrm{P}$ to the plant owing to its favourable effects on division and multiplication of cells. Moreover, phosphorus is the important constituent of coenzymes which are important for photosynthesis and protein synthesis. One of the main roles of the phosphorus in plant is in transfer of energy through ATP and also involved in root development and in metabolic activities. The results are in conformity with those reported by Agrawal and Pathak (2011), Devi et al., (2011), Jordan and Caldwell (2012), Saxena et al., (2013), Kaur and Reddy (2014) and Yousefi and Berzegar (2014).

\section{Effect of KSB}

Application of $45 \mathrm{~kg} \mathrm{~K}_{2} \mathrm{O} / \mathrm{ha}+\mathrm{KSB}$ seed inoculation $+\mathrm{KSB}$ soil application $\left(\mathrm{K}_{3}\right)$ recorded significantly the highest potassium uptake by grain $(18.27 \mathrm{~kg} / \mathrm{ha})$ and straw $(69.92 \mathrm{~kg} / \mathrm{ha})$. Significantly the highest total uptake of potassium $(88.18 \mathrm{~kg} / \mathrm{ha})$ was noted with application of $45 \mathrm{~kg} \mathrm{~K}_{2} \mathrm{O} / \mathrm{ha}+\mathrm{KSB}$ seed inoculation + KSB soil application $\left(\mathrm{K}_{3}\right)$, which maintained statistical equivalence with application of $45 \mathrm{~kg} \mathrm{~K} 2 \mathrm{O} / \mathrm{ha}+\mathrm{KSB}$ seed inoculation $\left(\mathrm{K}_{2}\right)$ (Table 1 and 2).

Table.1 Effect of different treatments on phosphorus and potassium uptake by grain and straw

\begin{tabular}{|c|c|c|c|c|c|c|}
\hline \multirow[t]{2}{*}{ Treatments } & \multicolumn{3}{|c|}{ Phosphorus uptake (kg/ha) } & \multicolumn{3}{|c|}{ Potassium uptake (kg/ha) } \\
\hline & Grain & Straw & Total & Grain & Straw & Total \\
\hline \multicolumn{7}{|l|}{ PSB } \\
\hline $\mathbf{P}_{0}:$ Control & 13.90 & 3.00 & 16.90 & 13.20 & 51.08 & 64.29 \\
\hline $\mathrm{P}_{1}: 60 \mathrm{~kg} \mathrm{P}_{2} \mathrm{O}_{5} / \mathrm{ha}$ & 15.67 & 4.61 & 20.29 & 14.71 & 62.11 & 76.82 \\
\hline 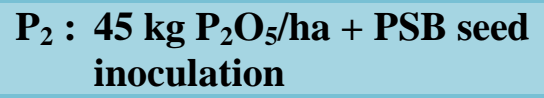 & 16.92 & 5.23 & 22.16 & 15.64 & 63.56 & 79.20 \\
\hline $\begin{aligned} \mathrm{P}_{3}: & 45 \mathrm{~kg} \mathrm{P}_{2} \mathrm{O}_{5} / \mathrm{ha}+\text { PSB seed } \\
& \text { inoculation + PSB soil } \\
& \text { application }\end{aligned}$ & 17.98 & 5.72 & 23.71 & 17.14 & 66.76 & 83.89 \\
\hline S.Em. \pm & 0.64 & 0.18 & 0.68 & 0.51 & 2.60 & 2.59 \\
\hline C.D. at $5 \%$ & 1.85 & 0.53 & 1.96 & 1.47 & 7.50 & 7.47 \\
\hline \multicolumn{7}{|l|}{ KSB } \\
\hline $\mathrm{K}_{0}:$ Control & 14.12 & 4.02 & 18.14 & 10.48 & 47.38 & 57.86 \\
\hline $\mathrm{K}_{1}: 60 \mathrm{~kg} \mathrm{~K} \mathrm{O} / \mathrm{ha}$ & 15.30 & 4.59 & 19.89 & 15.25 & 60.95 & 76.20 \\
\hline $\begin{aligned} \mathrm{K}_{2}: & 45 \mathrm{~kg} \mathrm{~K} \mathrm{~K} / \mathrm{ha}+\mathrm{KSB} \text { seed } \\
& \text { inoculation }\end{aligned}$ & 16.57 & 4.73 & 21.30 & 16.69 & 65.27 & 81.95 \\
\hline $\begin{aligned} \mathrm{K}_{3}: & 45 \mathrm{~kg} \mathrm{~K} \mathrm{O} / \mathrm{ha}+\mathrm{KSB} \text { seed } \\
& \text { inoculation }+\mathrm{KSB} \text { soil } \\
& \text { application }\end{aligned}$ & 18.49 & 5.23 & 23.72 & 18.27 & 69.92 & 88.18 \\
\hline S.Em. \pm & 0.64 & 0.18 & 0.68 & 0.51 & 2.60 & 2.59 \\
\hline C.D. at $5 \%$ & 1.85 & 0.53 & 1.96 & 1.47 & 7.50 & 7.47 \\
\hline
\end{tabular}


Table.2 Effect of different treatments on nutrient use efficiency and Apparent nutrient recovery (\%)

\begin{tabular}{|c|c|c|c|c|}
\hline \multirow[t]{2}{*}{ Treatments } & \multicolumn{2}{|c|}{$\begin{array}{c}\text { Nutrient use efficiency } \\
\text { (kg grain/kg fertilizer applied) }\end{array}$} & \multicolumn{2}{|c|}{$\begin{array}{l}\text { Apparent nutrient } \\
\text { recovery }(\%)\end{array}$} \\
\hline & Phosphorus & Potash & Phosphorus & Potash \\
\hline \multicolumn{5}{|l|}{ PSB } \\
\hline $\mathbf{P}_{0}:$ Control & 0.00 & 6.65 & 0.00 & 35.14 \\
\hline $\mathrm{P}_{1}: 60 \mathrm{~kg} \mathrm{P}_{2} \mathrm{O}_{5} / \mathrm{ha}$ & 5.30 & 5.64 & 5.64 & 37.39 \\
\hline $\begin{aligned} \mathrm{P}_{2}: & 45 \mathrm{~kg} \mathrm{P}_{2} \mathrm{O}_{5} / \mathrm{ha}+\mathrm{PSB} \\
& \text { seed inoculation }\end{aligned}$ & 11.44 & 7.48 & 11.67 & 41.22 \\
\hline $\begin{aligned} \mathrm{P}_{3}: & 45 \mathrm{~kg} \mathrm{P}_{2} \mathrm{O}_{5} / \mathrm{ha}+\mathrm{PSB} \\
& \text { seed inoculation }+ \text { PSB } \\
& \text { soil application }\end{aligned}$ & 14.97 & 9.13 & 15.11 & 37.72 \\
\hline \multicolumn{5}{|l|}{ KSB } \\
\hline $\mathrm{K}_{0}:$ Control & 7.24 & 0.00 & 7.68 & 0.00 \\
\hline $\mathrm{K}_{1}: 60 \mathrm{~kg} \mathrm{~K} \mathrm{O} / \mathrm{ha}$ & 8.09 & 3.36 & 8.30 & 30.57 \\
\hline $\begin{aligned} \mathrm{K}_{2}: & 45 \mathrm{~kg} \mathrm{~K} \mathrm{O} / \mathrm{ha}+\mathrm{KSB} \\
& \text { seed inoculation }\end{aligned}$ & 10.01 & 9.80 & 7.66 & 53.53 \\
\hline $\begin{aligned} \mathrm{K}_{3}: & 45 \mathrm{~kg} \mathrm{~K} \mathrm{~K} / \mathrm{ha}+\mathrm{KSB} \\
& \text { seed inoculation }+\mathrm{KSB} \\
& \text { soil application }\end{aligned}$ & 6.38 & 15.73 & 8.78 & 67.37 \\
\hline
\end{tabular}

The potash use efficiency and apparent potash recovery (\%) varied perceptibly under different treatments of potash. Wherein, the treatment $\mathrm{K}_{3}\left(45 \mathrm{~kg} \mathrm{~K} \mathrm{~K}_{2} \mathrm{O} / \mathrm{ha}+\mathrm{KSB}\right.$ seed inoculation + KSB soil application) registered the highest potash use efficiency $(15.73 \mathrm{~kg}$ grain/kg $\mathrm{K}$ applied) and apparent potash recovery (67.37\%), followed by the treatment $\mathrm{K}_{2}$ (application of $45 \mathrm{~kg} \mathrm{~K} 2 \mathrm{O} / \mathrm{ha}+\mathrm{KSB}$ seed inoculation) by recording potash use efficiency of $9.80 \mathrm{~kg}$ grain $/ \mathrm{kg} \mathrm{K}$ applied and apparent potash recovery of $53.53 \%$.

Scrutiny of data revealed that different levels of KSB exercised their significant influence on phosphorus uptake by grain, straw and total uptake. Significantly the highest phosphorus uptake by grain $(18.49 \mathrm{~kg} / \mathrm{ha})$, straw $(5.23 \mathrm{~kg} / \mathrm{ha})$, was registered with application of $45 \mathrm{~kg} \mathrm{~K}_{2} \mathrm{O} / \mathrm{ha}+\mathrm{KSB}$ seed inoculation $+\mathrm{KSB}$ soil application $\left(\mathrm{K}_{3}\right)$. The maximum total uptake of phosphorus (23.72 $\mathrm{kg} / \mathrm{ha}$ ) was found with application of $45 \mathrm{~kg}$ $\mathrm{K}_{2} \mathrm{O} / \mathrm{ha}+\mathrm{KSB}$ seed inoculation $+\mathrm{KSB}$ soil application $\left(\mathrm{K}_{3}\right)$. Application of $45 \mathrm{~kg} \mathrm{~K} \mathrm{~K}_{2} \mathrm{O} / \mathrm{ha}$ $+\mathrm{KSB}$ seed inoculation $\left(\mathrm{K}_{2}\right)$ registered the highest phosphorus use efficiency $(10.01 \mathrm{~kg}$ grain/kg P applied) and apparent phosphorus recovery $(8.78 \%)$, followed by application of $60 \mathrm{~kg} \mathrm{~K} \mathrm{~K}_{2} \mathrm{O} / \mathrm{ha}\left(\mathrm{K}_{1}\right)$ having phosphorus use efficiency of $8.09 \mathrm{~kg}$ grain $/ \mathrm{kg} \mathrm{P}$ applied and apparent phosphorus recovery of $8.30 \%$. The response of KSB may be attributed to mobilization of $\mathrm{K}$ from soil because of secretion of organic acids by the bacterial strains, thereby enhanced plant growth and development, and finally greater acquisition of nutrients. The results are supported by other workers who have observed increasein plant assimilation of $\mathrm{K}$ by the use of potassium solubilizing microorganisms in soil. These results are in close conformity with the finding of Bagyalakshami et al., (2012), Sangeeth et al., (2012), Min et al., (2013), Prajapati et al., (2013), Zhanga and Konga (2014) and Padma and Sukumar (2015). 


\section{References}

Agrawal, S. and Pathak, R.K. 2011. Response of phosphate solubilizing microorganism on quality of wheat (Triticum aestivum L.) plant grown conventionally in temperate climate. Asiatic Journal of Biotechnology Resources, 2(7): 814-820.

Anonymous (2017). Department of Agriculture, Cooperation \& Farmers Welfare, Government of India, KrishiBhawan, New Delhi.

Bagyalakshami, B., Ponmurugan, P. and Marimuthu, S. 2012. Influence of potassium solubilizing bacteria on crop productivity and quality of tea (Camellia sinensis). African Journal of Agricultural Research, 7(30): 42504259.

Basak, B.B. and Biswas, D.R. 2009. Influence of potassium solubilizing microorganism (Bacillus mucilaginosus) and waste mica on potassium uptake dynamics by Sudan grass (Sorghum vulgare Pers.) grown under two Alfisols. Plant and Soil, 317: 235-255.

Devi, K.N.; Singh, M.S.; Singh, N.G. and Athokpam, H.S. 2011. Effect of integrated nutrient management on growth and yield of wheat (Triticum aestivum L.).Journal of Crop and Weed, 7(2): 23-27.

Illmer, P.; Barbato, A. and Schinner, F. 1995. Solubilization of hardly soluble $\mathrm{AlPO}_{4}$ with P-solubilizing microorganisms. Soil Biology and Biochemistry, 27: 265-270.

Jordan, D.L. and Caldwell, D.F. 2012. Improvement of wheat and cotton growth and nutrient uptake by phosphate solubilizing bacteria. Proc. of the $26^{\text {th }}$ Southern Conservation Tillage Conference for Sustainable Agriculture, Raleigh, North Carolina,
USA, 8-9-June, 2004, pp. 58-66.

Kaur, G. and Reddy, M.S. 2014. Influence of P-solubilizing bacteria on crop yield and soil fertility at multilocational sites. European Journal of Soil Biology, 61: 35-40.

Min, Z.A.; Yong, Z.G.; Feng, Z.S.; Ying, Z.R. and Cheng, Z.B. 2013. Effect of phosphorus and potassium content of plant and soil inoculated with Paneibacillus kribensis CX-7 strain antioxidant and antitumor activity of Phyllanthus emblica in colon cancer cell lines. International Journal of Current Microbiology and Applied Science, 2(6): 273-279.

Padma, S.D. and Sukumar, J. 2015. Response of mulberry to inoculation of potash mobilizing bacterial isolation and other bio-inoculants. Global Journal of Bioscience and Biotechnology,4(1): 50-53.

Panda, S.C. 2012. A Handbook of Agriculture. Agrobios (India), Jodhpur. p. 1264.

Ponmurugan, P. and Gopi, C. 2006. In vitro production of growth regulators and phosphate activity by phosphate solubilizing bacteria. African Journal of Biotechnology, 5: 348-350.

Prajapati, K.; Sharma, M.C. and Modi, H.A. 2013. Growth promoting effect of potassium solubilizing microorganisms on okra (Abelmoschus esculentus). International Journal of Agricultural Science and Research, 3(1): 181-188.

Sangeeth, K.P.; Bhai, R.S. and Srinivasan, V. 2012. Paenibacillus glucanolyticus, a promising potassium solubilizing bacterium isolated from black pepper (Piper nigrum L.) rhizosphere. Journal of Spices and Aromatic Crops, 21(2): 118-124.

Saxena, M.J.; Chandra, S. and Nain, L. 2013. Synergistic effect of phosphate 
solubilizing rhizobacteria and arbuscular mycorrhiza on growth and yield of wheat plants. Journal of Soil Science and Plant Nutrition, 13(2): 511-525.

Yousefi, A.A.; and Berzegar, A.R. 2014. Effect of Azotobacter and Pseudomonas bacteria inoculation on wheat yield under field condition.
International Journal of Agriculture and Crop Sciences, 7 (9): 616-619

Zhanga, C. and Konga, F. 2014. Isolation and identification of potassiumsolubilizing bacteria from tobacco rhizospheric soil and their effect on tobacco plants. Applied Soil Ecology, 82: $18-25$.

\section{How to cite this article:}

Savaliya, N.V. Vipen Bhadu, R.A. Barsiya and Vadaliya, B.M. 2018. Promotion of Nutrient Uptake, Nutrient Use Efficiency and Apparent Nutrient Recovery of Wheat (Triticum aestivum L.) by Application of Phosphate and Potash Solubilizing Bacteria. Int.J.Curr.Microbiol.App.Sci. 7(07): 2446-2452. doi: https://doi.org/10.20546/ijcmas.2018.707.286 